\title{
Financial Depth in the WAEMU Benchmarking Against Frontier SSA Countries
}




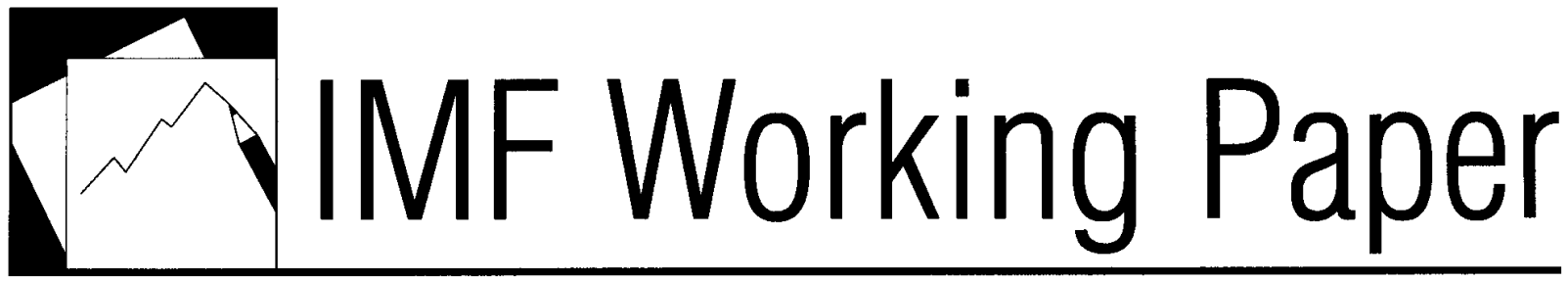

Financial Depth in the WAEMU: Benchmarking Against Frontier SSA Countries

Calixte Ahokpossi, Kareem Ismail, Sudipto Karmakar, and Mesmin Koulet-Vickot 


\title{
IMF Working Paper
}

\author{
African Department
}

\section{Financial Depth in the WAEMU: Benchmarking Against Frontier SSA Countries ${ }^{1}$}

\section{Prepared by Calixte Ahokpossi, Kareem Ismail, Sudipto Karmakar, Mesmin Koulet-Vickot}

Authorized for distribution by Michel Lazare

July 2013

\section{This Working Paper should not be reported as representing the views of the IMF.}

The views expressed in this Working Paper are those of the author(s) and do not necessarily represent those of the IMF or IMF policy. Working Papers describe research in progress by the author(s) and are published to elicit comments and to further debate.

\begin{abstract}
Financial depth in Sub-Saharan Africa (SSA) has been uneven over the last two decades. The WAEMU countries are lagging behind other regions, particularly the High Growth Non-oil Exporters (HGNOEs) group. We use two complementary methodologies to compare the two groups of countries. In a panel of 16 countries over 1997-2009, we find that the financial gap between the two groups of countries can be explained by institutional factors. In a benchmarking exercise comparing the major economy in the WAEMU (Côte d'Ivoire) with the most structurally similar in the control group (Mozambique), we show that Côte d'Ivoire underperformed relative to Mozambique and to its estimated potential. We then identify policy and institutional asymmetries between the two countries that could explain the gap in performance.
\end{abstract}

JEL Classification Numbers: E51, G28

Keywords: Financial development, Financial possibility frontier, Benchmarking, WAEMU Author's E-Mail Address: CAhokpossi@imf.org; KIsmail@imf.org; SKarmakar@imf.org; MKouletVickot@,imf.org

\footnotetext{
${ }^{1}$ We benefited from comments received at a seminar in the African Department of the IMF where an earlier version of the paper was presented. We are also grateful for useful comments from Michel Lazare, Doris Ross, Patrick Gitton, Patrick Imam, Paul Mathieu and Fabien Nsengiyumva.
} 


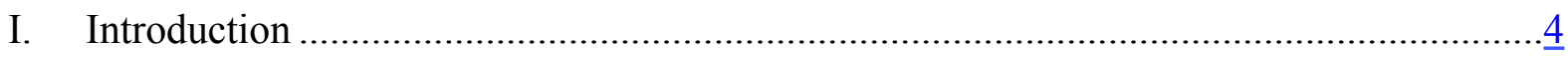

II. Stylized Facts and Empirical Literature Review ..................................................

III. The Regression Analysis ..................................................................................

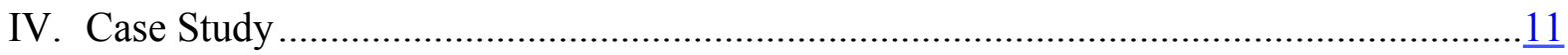

A. Where Côte d'Ivoire Stands Relative to Mozambique and to its Potential? ..............11

B. Explaining the Financial Development Gap ...............................................

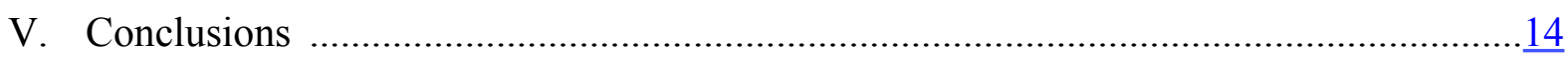

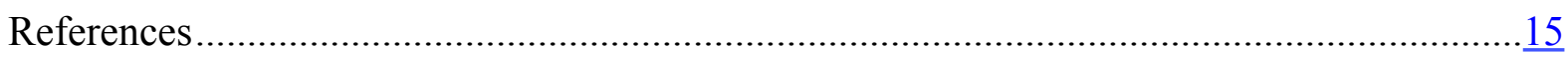

Tables

1. Descriptive Statistics, 1997-2009 _..............................................................17

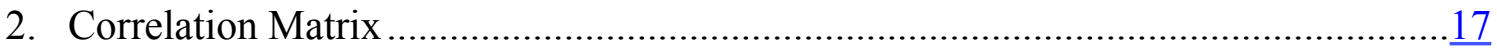

3. Variables Definitions................................................................................ 18

4. Financial Development in WAEMU and HGNOE in SSA, 1997-2009..................19

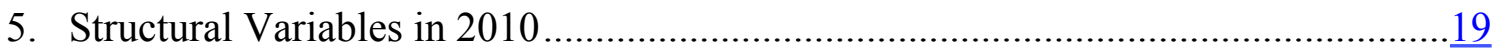

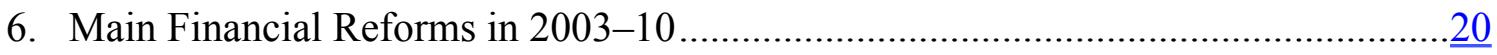

Figures

1. Credit to the Private Sector ..............................................................................

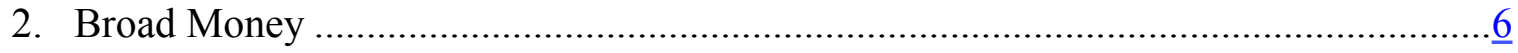

3. Return on Assets and Return on Equity ............................................................

4. Private Credit/GDP (\%) ..................................................................... 12

Annex

1. Financial Possibility Frontier: Benchmarking WAEMU Against HGNOES .............21

2. Benchmarking WAEMU Countries Against Their Potential...................................23 


\section{INTRODUCTION}

The importance of financial development for broad-based economic growth is widely recognized. The empirical literature has demonstrated that countries with higher levels of financial development tend to grow faster. ${ }^{2}$ Of all measures of financial development, depth measured by either the ratio of liquid liabilities to GDP or by the ratio of private credit to GDP, has been particularly challenging to improve in Sub-Saharan Africa. Deeper financial systems with wider access to credit help promote and support entrepreneurship and social mobility and thus are vital for broad-based economic growth. Therefore, identifying factors that promote financial deepening, and explain differences across countries on that dimension,warrants closer examination.

In Sub-Saharan Africa (SSA), financial development has been uneven across regions and remains a critical policy challenge despite progress over the past two decades. The focus of this paper is to examine where the West African Economic and Monetary Union ${ }^{3}$ (WAEMU) stands relative to some selected economies in the SSA and which factors may help explain this performance. The benchmark group is comprised of some frontier SSA countries, the High Growth Non-Oil Exporters (HGNOEs). ${ }^{4}$ The novelty of this paper is that: i) it focuses on a group of African countries with shared monetary and financial policies, and compares it to a group of high performing countries in SSA, and; ii) it uses two complementary empirical approaches to compare the two groups of countries: first, a regression analysis to identify the factors that explain the difference in financial depth between the WAEMU and the control group, and second, a case study to benchmark the biggest and most financially advanced economy in the WAEMU (Côte d'Ivoire) against a comparable country in the control group (Mozambique). The case study is based on the financial benchmark methodology developed by the World Bank (Beck et. al., 2010; Feyen and Kibuuka, 2012). Our analysis is based on a panel of 16 countries (eight countries from the WAEMU, and eight HGNOEs) over the period 1997-2009. Over that time period, FSAPs (the IMF's Financial System Assessment Program) were performed on both Côte d'Ivoire and Mozambique, which helps us account for the structural reforms underlying the difference in financial deepening between the two countries. Moreover, the period is sufficiently long to capture the lagged impact of policy reforms on improving the financial environement. The results are consistent with the literature: we show that stronger rule of law, infrastructure, and credit information collection and dissemination have a strong impact on financial depth.

\footnotetext{
${ }^{2}$ See Levine and Zervos (1998) and Khan and Senhadji (2000).

${ }^{3}$ The WAEMU countries are Benin, Burkina Faso, Côte d'Ivoire, Guinea-Bissau, Mali, Niger, Senegal, and Togo. The eight countries are all members of the CFAF currency zone.

${ }^{4}$ The High Growth Non-Oil Exporters (HGNOEs) are the countries with an average per capita growth rate of at least 3 percent during 1995-2009. Eight frontier SSA countries fall into this category: Botswana, Cape Verde, Ethiopia, Mauritius, Mozambique, Rwanda, Tanzania, and Uganda. (cf. IMF, African Regional Economic Outlook, October, 2010).
} 
The rest of this paper is structured as follows. Section II discusses stylized facts and related literature; section III presents empirical evidence on factors hindering financial deepening in the WAEMU; section IV introduces a case study examining the divergence in experience between Côte d'Ivoire and Mozambique; and section V draws conclusions.

\section{STYLIZED FACTS AND EMPIRICAL LITERATURE REVIEW}

In the literature, financial depth is generally measured by either the ratio of liquid liabilities to GDP or the ratio of private credit to GDP. Although these two measures are correlated, they have different focuses. The liabilities side measure captures the degree of mobilization of monetary resources as a share of GDP, while the credit measure focuses on the extent to which banks finance economic activity. ${ }^{5}$ The figures below compare the WAEMU to the control group along these two basic indicators of financial depth, as well as two measures of efficiency. It appears that the WAEMU is lagging relative to the control group. In the WAEMU, the ratio of private sector credit to GDP increased marginally from 12 percent to 17 percent between 1997-2009, while it accelerated from 17 percent to 37 percent of GDP in the control group (Figure 1). The ratio of broad money to GDP, a measure of the degree of monetization, followed a similar profile. Broad money relative to GDP grew from 31 percent to 52 percent in the benchmark countries, while rising from 20 percent to 29 percent in the WAEMU over the period (Figure 2).

The banking system in the WAEMU is not only shallower compared to the benchmark countries, but it is also less profitable. Return on assets, weighted by bank assets, remained constant around 1.3 percent in the WAEMU, half of the level in HGNOEs (Figure 3). The contrast is also striking for return on equity (Figure 3).

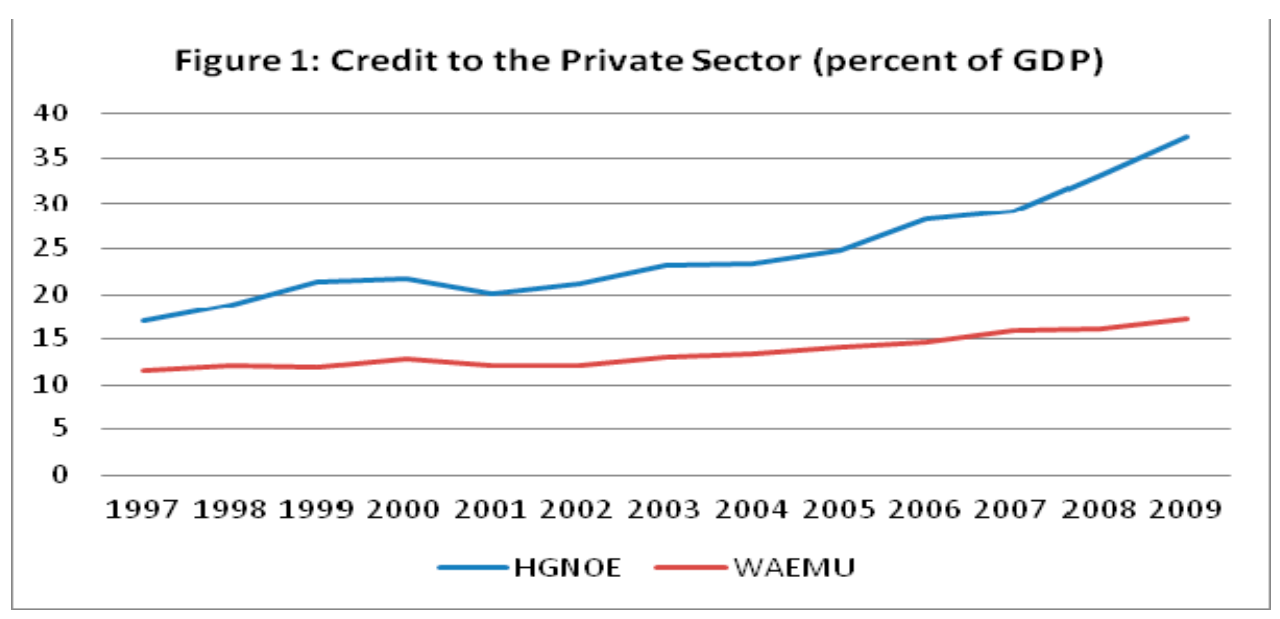

\footnotetext{
${ }^{5}$ Both indicators are measures of size of the banking system, and do not give any indications on its efficiency or access to financial services.
} 
Source: Bankscope database.

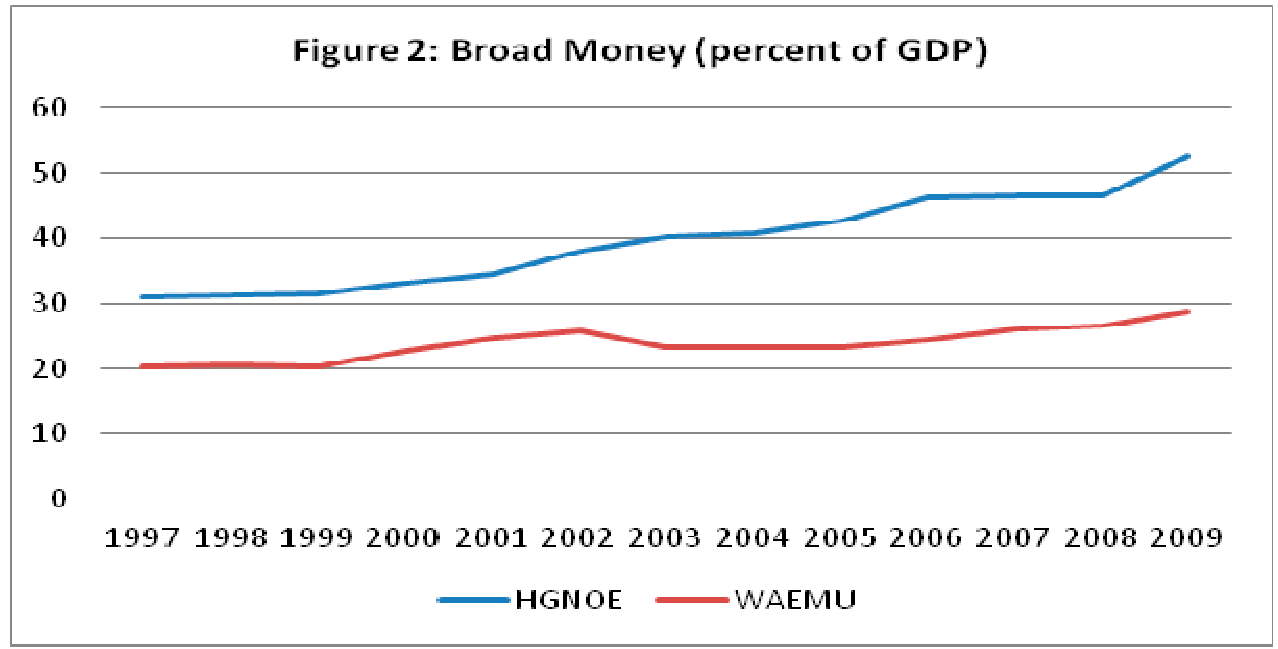

Source: Bankscope database.

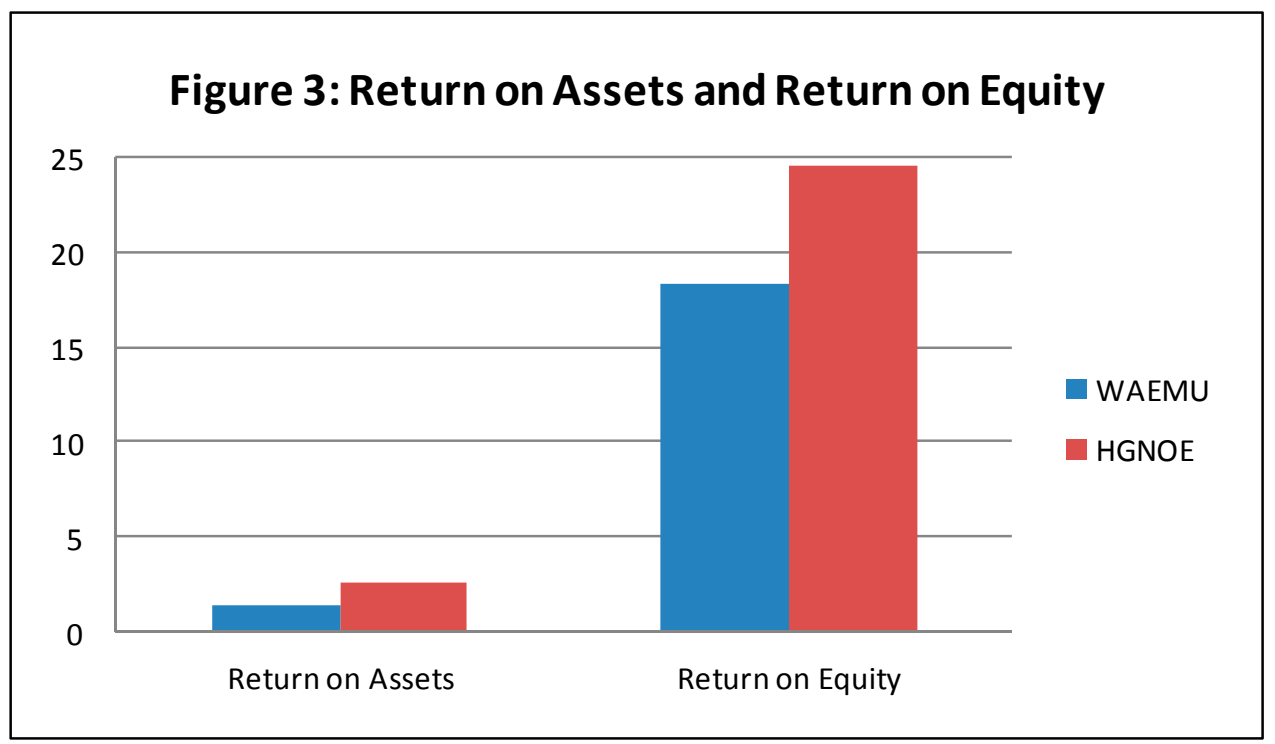

Source: Bankscope database.

In explaining the differences in financial depth across countries, the empirical literature distinguishes between structural factors and policy factors. ${ }^{6}$ Structural factors are countryspecific characteristics that cannot be altered by policies in the short run. These include the overall level of economic development and other characteristics such as population size and density, age dependency. The overall level of development, measured by per capita income, can effect financial depth through elevating demand for financial services and higher supply

\footnotetext{
${ }^{6}$ Demirguc-Kunt (2006) provides a comprehensive survey of the explanatory variables used in empirical analysis.
} 
of savings. Countries with larger populations and higher population density can have deeper financial penetration and lower cost of financial intermediation from economies of scale. The share of non-working young and old populations (age dependency) affects savings and lending patterns. Policy factors are those that may impact the banking environment including macroeconomic policies (such as inflation, fiscal balance, and debt), institutional policies (regulatory and supervisory framework, accounting and disclosures practices, credit information and contract enforcement), and other financial sector reforms that may liberalize credit markets or enhance market compeititon.

There is evidence in the literature that both structural factors and macroeconomic policies can have an impact on financial deepening. Levine (2003) and Claessens and Feijen (2006) show the importance of overall economic development, measured by per capita income. On macroeconomic policies, Detragiache et al. (2005) find a negative impact of inflation on financial depth, while Boyd et al. (2001) highlight the non-linear relationship between inflation and financial development.

Looking beyond macroeconomic performance, there is also evidence that contract enforcement, credit infrastructure, and market liberalization play an important role. Using bank-level cross sectional data, Demetriades and Fielding (2011) investigate the determinants of individual banks' loans in the WAEMU, and find that banks are reluctant to lend, despite excess liquidity ${ }^{7}$ and low inflation, because the infrastructure to screen and monitor borrowers is not developed. Governance in all its aspects (government effectiveness, control of corruption, and rule of law) also plays a role. Detragiache, Gupta and Tressel (2005) find that contract enforcement and property rights matter in financial development. Sacerdoti (2005) explains the low ratio of credit to private sector to GDP by a deficiency in the supporting institutional framework. Ghura, Kpodar, and Singh (2009) explain low financial depth in the CFA franc zone countries through the weaker legal, contractual, and institutional environment in the region compared to SSA. Using the financial liberalization index constructed by McDonald and Schumacher (2007) that captures some aspects of financial reforms (credit controls, interest rate controls, informal financial sector), Ghura, Kpodar, and Singh (2009) find that this aggregate index is related to greater depth in financial development.

\footnotetext{
${ }^{7}$ The excess liquidity in the WAEMU, in addition to the lower development of government securities market, suggests that the factor behind the lower ratio of private credit compared to the control group is not due to government crowding out of the private sector.
} 


\section{THE REGRESSION ANALYSIS}

In this section, we analyze the difference between financial depth in the WAEMU and in the comparator group, after controlling for other relevant factors. In our empirical analysis, the measure of financial sector depth is credit to the private sector as a share of GDP, which reflects the extent of financial intermediation in Sub-Saharan Africa and the interlinkage between economic activity and the financial system better than other liabilities-based measures. The analysis is based on a panel of 16 countries over the period 1997-2009 at annual frequency. The panel analysis allows us to track the WAEMU countries over a relatively long time horizon and compare them with other peer economies. We use macroeconomic data from the IMF International Financial Statistics, and indicators on institutions, political stability, and credit infrastructure from the World Bank.

We estimate credit to the private sector as a share of GDP using the following model:

$$
S_{c, t}=\alpha_{1}+\sum_{j} \beta_{j} X_{c, t}^{j}+\sum_{m} \beta_{m} Y_{c, t}^{m}+d_{t}+v_{i, t}
$$

Where the vector $X_{c, t}$ contains macroeconomic variables specific to country c at time t. $Y_{c, t}$ contains country-specific institutional and policy variables. $d_{t}$ is a vector of dummy variables that takes a value 1 if the country belongs to the WAEMU region and zero otherwise.

The macroeconomic indicators include the log of GDP per capita and the log of inflation. Per capita GDP measures the overall level of economic development and is expected to positively affect credit to the private sector. As income rises, demand for financial services increases and that might lead to better penetration. Also with higher income, there might be greater savings, which means the banks will have more resources to lend from. Low inflation is considered as a sign of macroeconomic stability, which promotes financial intermediation. Thus the expected coefficient sign for inflation is negative.

Policy and institutional variables include indices on rule of law, political stability, credit coverage, internet coverage among adults, and the quality of contract enforcement. The rule of law represents a measure of the extent to which banks have faith in contract enforcement, police, and courts, and the likelihood of crime and violence. A strong rule of law is expected to create an environment conducive to bank lending. Property rights captures the dimension of rule of law related to the strength of collateral entitlements and enforcement, which helps banks extend collateralized credit. Political stability, measured here by the perceptions of the likelihood that the government will be destabilized or overthrown by unconstitutional or violent means (Worldwide Governance Indicators) is another factor that we consider in explaining financial penetration. When the political environment is stable, there is less uncertainty, and banks are more willing to lend. The quality of contract enforcement, measured by the number of days required to enforce a contract, is also an important 
determinant of bank lending. The greater the number of days needed to enforce a contract, the costlier is borrowers default for bank, and thus the smaller is the amount of credit they disburse. Credit coverage captures the quality of credit information. Credible credit bureaus encourage the expansion of credit as they enable on the one hand lenders to better screen borrowers, assess and manage risks, and on the other hand borrowers to gain access to finance. Internet coverage is used as a proxy for infrastructure development, which reduces the cost of bank penetration and helps improve bank geographical coverage. A good internet coverage indicates a solid telecommunication infrastructure, which is critical to/for bank transactions and transfers.

Tables 1 and 2, respectively, show some descriptive statistics and correlations. Credit to the private sector relative to GDP is most correlated with infrastructure, rule of law, and GDP per capita. Various measures of the quality of legal environment (rule of law, property rights and political stability) are highly correlated with each other, suggesting that they may be measuring similar attributes of the credit environment.

To further the analysis, we used a two-step Feasible Generalized Least Squares (FGLS) to estimate the model above. ${ }^{8}$ The estimation approach allows us not only to address issues of heteroscedasticity, but also to estimate the impact of time-invariant variables such as the WAEMU dummy, while controlling for country-specific effects. Several model specifications have been estimated and the results are presented in Table 4.

The WAEMU dummy is negative and significant even after controlling for macroeconomic variables (Table 4, column 1), thereby providing evidence that financial deepening is indeed weaker in the WAEMU than in high growth non-oil exporting countries in Sub-Saharan Africa. The sign and significance of the WAEMU variable are, however, not stable when policy and institutional factors are accounted for.

As expected, macroeconomic variables are important determinants of credit to the private sector relative to GDP. The impact of inflation is negative and significant in most specification of the model. Per capita GDP is positively associated with the financial depth in all specifications.

Looking at institutional/policy variables, we find that political stability, availability of information on borrowers, strength of legal framework, and quality of infrastructure are associated with deeper financial markets (Table 4, columns 2-6). The introduction of some of these variables substantially weakens the control variable for WAEMU countries,

\footnotetext{
${ }^{8}$ The first step estimates an OLS and collects the residuals; the second step estimates generalized least squares with a variance matrix build from the residuals collected in the first step.
} 
suggesting that they may explain away most of the differences in financial depth between the WAEMU and HGNOEs.

Both rule of law and property rights capture the quality of the legal environment and are highly correlated (Table 2). They both are significantly associated with financial depth (Table 4, columns 2 and 6). However, the introduction of rule of law in the regression weakens the WAEMU control variable, which becomes insignificant. ${ }^{9}$ In other words, once rule of law is accounted for, the difference between the WAEMU group and the HGNOEs becomes statistically insignificant. This result is in line with the literature that finds that a stronger legal framework promotes financial development as depositors can provide longer term savings and banks can extend more credit as they have a greater chance at recovering non-performing assets through courts.

The results also indicate that political stability matters for financial depth (Table 4, column 3). In a politically stable environment, banks have more confidence to lend because there is less uncertainty and a greater chance of recovering their outlays. While political stability matters, it does not explain away the differences between the WAEMU and the HGNOEs, as the WAEMU control variable remains significant.

Quality of infrastructure, as measured by internet coverage, positively affects financial depth (Table 4, column 4). It also explains away the difference in financial depth between the WAEMU and HGNOEs. Better infrastructure allows financial institutions to reach borrowers at a lower cost, thereby encouraging more lending.

Information on borrowers as measured by credit coverage is another important factor that is positively associated with financial depth (Table 4, column 5). ${ }^{10}$ The introduction of credit coverage in the regression also explains away the difference between the WAEMU and HGNOEs. If banks have more information on their customers, they will screen them better and will engage in greater lending as they will be less exposed to defaults. Small and medium-sized enterprises (SMEs) and other entrepreneurs with good quality projects and good track-record will have access to credit and be able to undertake profitable investment projects.

Overall, the results show that the difference in financial depth between the WAEMU and HGNOEs is explained by the quality of the legal environment, infrastructure, and information available on borrowers. When rule of law, property rights and political stability

\footnotetext{
${ }^{9}$ The introduction of property rights slightly weakens the WAEMU dummy, which remains significant.

${ }^{10}$ This result of this regression should be interpreted with care, as the sample size drops substantially due to limited data on credit coverage. Also, for this reason, we do not further explore the impact of credit coverage on credit to the private sector in the presence of other explanatory variables.
} 
are simultaneously introduced in the model, only rule of law is significant (Table 4, column 7), indicating that there is some overlap in the dimension of the institutional environment measured by these variables.

\section{CASE STUDY}

After documenting that the WAEMU region fares poorly when pitted against some other peer countries of the SSA region and identifying some of the key variables contributing to the underdevelopment, we further deepen the empirical analysis by exploring where Côte d'Ivoire ${ }^{11}$ stands relative to its potential, and in relation to Mozambique - a country which appears to be the most structurally similar to Côte d'Ivoire. ${ }^{2}$ While Mozambique does not have the most developed financial sector in the control group, it shares many key structural similarities with Côte d'Ivoire such as population and dependency ratios. In that sense, financial sector differences between Côte d'Ivoire and Mozambique can be largely attributed to differences in policy. Table 5 compares Côte d'Ivoire and Mozambique with respect to several structural characteristics used in the financial benchmarking literature. To benchmark Côte d'Ivoire against Mozambique, we first use FinStat ${ }^{13}$ then we document policy asymmetries that might explain the difference between the two countries.

\section{A. Where Côte d'Ivoire Stands Relative to Mozambique and to its Potential?}

Figure 4 shows that for much of this period, Côte d'Ivoire and Mozambique were almost on par in terms of financial depth with private sector credit to GDP at around 15 percent for each in 2007. But Mozambique started outperforming Côte d'Ivoire thereafter. Comparison with the expected $75^{\text {th }}$ percentile ${ }^{14}$ provides additional insights as it shows that Côte d'Ivoire systematically underperformed relative to its potential over the period. The deviation of Côte d'Ivoire's private credit levels from its statistical benchmark and in relation with Mozambique suggests that there is possible policy and institutional gaps in the country. The

\footnotetext{
${ }^{11}$ Financial infrastructure and activities were not much affected by the internal crisis of the last decade. In particular, the south of Côte d'Ivoire, the financial and economic center of the country accounting for the bulk of GDP was under the government's control during the socio-political crisis of 2002-2007. However, in the absence of crisis the financial sector might have developed faster.

${ }^{12}$ Based on GDP per capita and population, Feyen and Kibuuka (FinStats, 2012) find that Mozambique is the most structurally similar to Côte d'Ivoire among the control group of countries.

${ }^{13}$ The detailed methodology is described in Annex 1.

${ }^{14}$ This is the value under which 75 percent of countries with the structural characteristics of Côte d'Ivoire are expected to be.
} 
next section aims to identify factors explaining why Côte d'Ivoire is lagging relative to Mozambique and to its potential. ${ }^{15}$

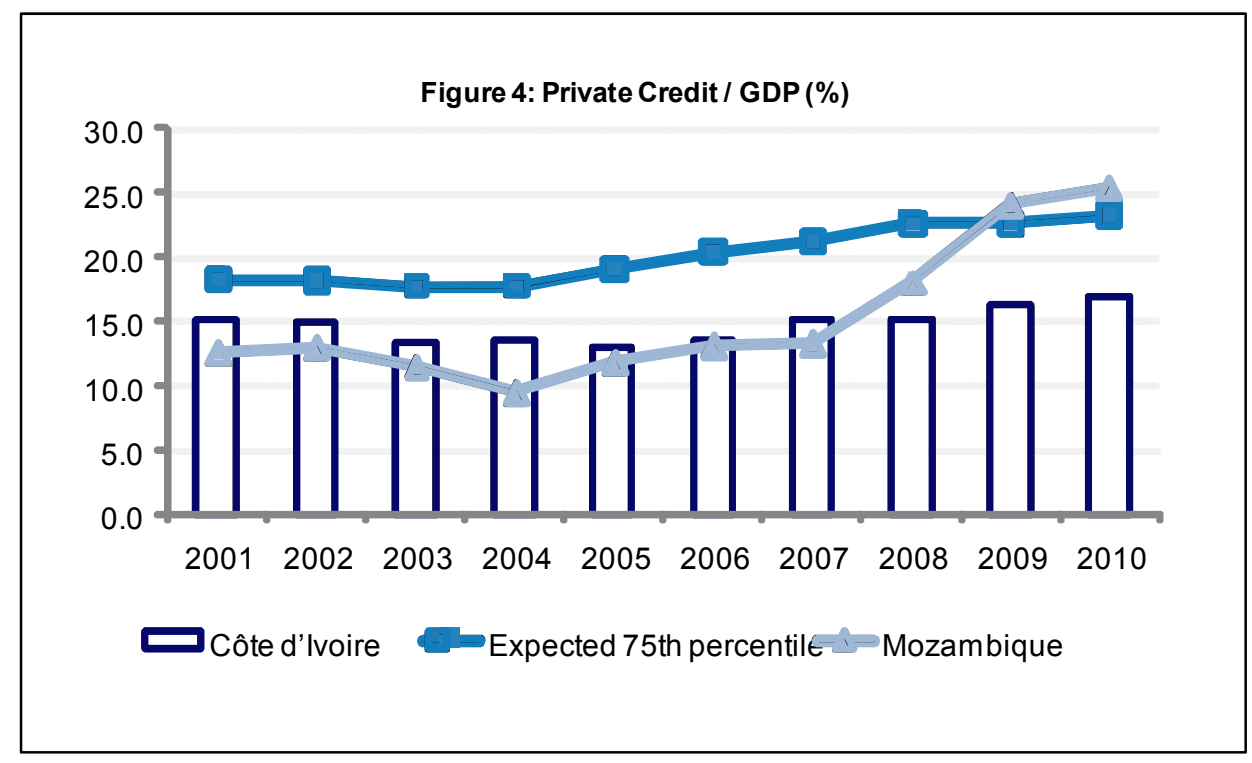

Source: FinStats.

\section{B. Explaining the Financial Depth Gap}

We referred to the Financial System and Stability Assessment Reports and the World Bank's Doing Business reports to explain the weak performance of Côte d'Ivoire relative to Mozambique and to its potential. We observe differences between Mozambique and Côte d'Ivoire during the covered period in terms of strength of contract enforcement and credit information, two essential factors in expanding credit availability.

Mozambique's government took forceful actions in strengthening contract enforcement, with the establishment of a specialized commercial court, the increase by 10 percent of the number of new judges, and the introduction of performance measure. As a result, the time taken to resolve a commercial dispute fell by 72 percent. Doing Business 2008 cited Mozambique as the top performer in contract enforcement in Africa. Second, a new legal framework for credit registries has been enacted in Mozambique, which resulted in

\footnotetext{
${ }^{15} \mathrm{We}$ also looked at where the other WAEMU countries stand relative their potential. We found that, except Senegal, all the other countries perform below their potential. The graphs are displayed in annex 2 . These countries belong to the same monetary union, and they share the same monetary policy and a common regulator of the financial sector. As such, the financial sector development issues in these countries are similar to those we detail below for Côte d'Ivoire.
} 
expanding the scope and accessibility of credit information. According to World Bank's Doing Business 2009, the depth of the credit information index improved from 3 to 4 , out of a possible 6 .

Finally, several other reforms undertaken by Mozambique's authorities over this period helped increase the flow of credit (FSAP, 2009). These include: (i) transitioning from an overall-compliance supervisory regime to risk-based supervision, which improved Bank of Mozambique's adaptability to risks and its monitoring of a broader range of vulnerabilities, while forcing supervisors to closely inspect bank balance sheets; (ii) enhancing the financial infrastructure by significantly improving the national payments system; (iii) a new legislation on microfinance; and (iv) limiting the dollarization of loans by raising the provisioning requirement on foreign exchange loans to non-exporters.

The increased financial depth in the case of Mozambique was just one of several positive outcomes of the broad reform agenda. Other gains include:

- a massive restructuring and clean up of bank balance sheets, which reduced non-performing loans (NPLs) from 17 percent of gross loans in 2003 to 2.8 percent in September 2008;

- an increase in banks' outreach with a rise in the number of branches and ATM machines, particularly in rural and semi-urban areas. Credit however remained heavily concentrated with limited credit for small and medium-sized enterprises and non-salaried individuals;

- a sharp rise in the number of microfinance institutions from 19 in 2003 to 87 in 2008.

Meanwhile, contrary to Mozambique, Côte d'Ivoire has not made any significant in-roads in addressing weaknesses in institutional environment that hinder financing deepening (Regional FSAP 2007-08 and FSAP 2009). ${ }^{16}$ No major progress has been recorded in improving the legal and judicial framework, nor in the credit information infrastructure. As pointed out by the FSAP 2009, the legal and judicial framework was unpredictable and offered little security for credit activities; contract enforcement was costly and slow; and credit information infrastructure remained deficient—-the country being rated 1 out of 6 in terms of the depth of credit information by Doing Business2010. In addition, the financial

\footnotetext{
${ }^{16}$ Some steps have been taken by the Ivoirian authorities in 2011-12. This includes the creation of commercial courts in January 2012 and the adoption of a decree on the enforcement of arbitration court decisions (exequatur) in February 2012. Efforts to simplify business activities (starting a business, registering properties) are also underway. Financial sector policies are mostly defined at the regional level, limiting the ability of Côte d'Ivoire to promptly take needed measures in this area; however, there is a scope to national financial sector policies: the restructuring of public banks, the definition of the role of the state in the financial sector.
} 
position of microfinance institutions was worrisome, with the largest networks virtually bankrupt. Table 1 compares Mozambique and Côte d'Ivoire along several facets of financial reforms over the period 2003-2010. These institutional weaknesses discourage lending activities and explain why Côte d'Ivoire's financial depth lied below its potential.

This comparison between Côte d'Ivoire and Mozambique sheds light on the role of institutional factors in financial deepening. However, despite the recent improvements, Mozambique continues to face many challenges in its institutional environment. While establishing the commercial court was a necessary step, enforcement of collateral remains costly and slow. Further progress is needed in addressing credit information infrastructure and national payment system shortcomings, as well as increasing competition. As a result, several key indicators in Mozambique remained stagnant. Particularly, excess liquidity remained high, and lending to agriculture remained anemic at below 10 percent of total loans for most of the period. These indicators reflect the extent of the challenge of boosting rural financing given the weak infrastructure and property rights, as well as the lack of long-term financing resources due to the short-maturity of liabilities.

\section{CONCLUSIONS}

This paper compares the experience of countries with varying infrastructure and institutional quality and policy regimes within Sub-Saharan Africa on financial sector development, specifically credit to the private sector as a share of GDP. We find evidence that stronger rule of law, infrastructure, and credit information collection and dissemination lead to higher bank lending to the private sector. Particularly, the paper makes the argument that these factors played a key role behind the advancement of financial depth in high-growth non-oil exporting countries and may explain the relatively poor performance in the WAEMU region. These results are in line with other empirical studies that highlighted the role of institutions, particularly the effectiveness of the legal/judicial framework, in promoting financial intermediation and bank lending.

The paper goes further into details of the policies that may be behind the slower financial development in WAEMU by contrasting the experience of Côte d'Ivoire (the biggest economy in the WAEMU) with Mozambique (a comparable country in the control group). We find the key contrast to be stronger policies in Mozambique on banking supervision, commercial courts, and credit information collection and dissemination. Reforms in these areas may explain how from 2007-2010, private sector credit to GDP rose in Mozambique from less than 15 percent to almost 25 percent - a 10 percentage point gain — while in Côte d'Ivoire the increase was less than one fourth of that. 


\section{REFERENCES}

"Enhancing Financial Sector Surveillance In Low Income Countries-Background Paper", 2012, International Monetary Fund.

"Enhancing Financial Sector Surveillance In Low Income Countries-Financial Deepening and Macro-Stability", 2012, International Monetary Fund.

Adarov, A., and R, Tchaidze, 2011, "Development of Financial Markets in Central Europe:

The Case of the CE4 Countries", IMF Working Paper WP/11/101 (Washington: International Monetary Fund).

Amadou N. R. Sy, 2006, "Financial Integration in the West African Economic and Monetary Union”, IMF Working Paper WP/06/214 (Washington: International Monetary Fund).

Andianova, S., Baltagi, B., Demetriades, P., and D. Fielding, 2011, "Why Do African Banks Lend So Little", University of Leicester, UK.

Babatounde, L, A., 2010, "Efficiency of Financial Micro Intermediation in the WAEMU Countries: A Stochastic Production Function Analysis", Munich Personal RePec Archive.

Beck, T., Feyen, E., Ize, Alain and Moizeszowicz, F., 2008, "Benchmarking Financial Development", Policy Research Working Paper, The World Bank.

Boyd J. H., R. Levine, B. D. Smith, 2001: "The Impact of Inflation on Financial Sector Performance", Journal of Monetary Economics 2001; 47 (2):221-248.

Claessens, Stijn \& Feijen, Erik, 2006. "Finance and Hunger: Empirical Evidence of the Agricultural Productivity Channel," Policy Research Working Paper Series 4080, The World Bank.

Demetriades, P., and D, Fielding, 2011, "Information, Institutions and Banking Sector Development in West Africa" Western Economic Association International (ISSN-0095-2583).

Demirguc-Kunt, Asli, 2006. "Finance and Economic Development: Policy Choices for Developing Countries, "Policy Research Working Paper Series 3955, The World Bank.

Detragiache, E., Gupta, P., and T, Tressel, 2005, "Finance in Lower Income Countries: An Empirical Exploration”, IMF Working Paper WP/05/167 (Washington: International Monetary Fund).

Flamini, V., McDonald, C., and L. Schumacher, 2009, “The Determinants of Commercial Bank Profitability in Sub-Saharan Africa”, Working Paper, WP/09/15. (Washington: International Monetary Fund).

Gaertner, M., and S. Sanya, 2012, “Assessing Bank Competition Within the East African Community.” IMF Working Paper, WP/12/32. (Washington: International Monetary Fund). 
Ghura, D., Kpodar, K., and R.J, Singh, 2009, "Financial Deepening in the CFA Franc Zone: The Role of Institutions", IMF Working Paper WP/09/113 (Washington: International Monetary Fund).

Honohan, P., and Beck T., 2007, "Making Finance Work for Africa, The World Bank. International Monetary Fund (IMF), 2010, "Sub-Saharan Africa: Resilience and Risks", Regional Economic Outlook, October 2010.

Kablan., S., "Banking Efficiency and Financial Development in Sub-Saharan Africa" IMF Working Paper WP/09/1 (Washington: International Monetary Fund).

Kablan., S., "Measuring Bank Efficiency in Developing Countries: The case of WAEMU", 2007, African Economic Research Consortium .

La Porta, R., F. Lopez-de-Silanes, A. Shleifer, and R. Vishny, 1998, "Law and Finance," Journal of Political Economy, Vol. 106, No. 6, pp. 1113-55.

Leon, F., 2012, "Financial Sector Competition in WAEMU”, CERDI, Etudes et Documents 2012.14

Levine, R., and S. Zervos, 1998, "Stock Markets, Banks, and Economic Growth," American Economic Review, 88, 537-558.

Levine, R., 2003, "More on Finance and Growth: More Finance, More Growth?" Federal Reserve Bank of St. Louis Review, 85(4), 2003, 31-46

McDonald, C., and L. Schumacher, 2007, "Financial Deepening in Sub-Saharan Africa: Empirical Evidence on the Role of Creditor Rights Protection and Information Sharing," IMF Working Paper, WP/07/203.

Maechler, A., Mitra, S., and D, Worrell, 2007, "Decomposing Financial Risks and Vulnerabilities in Eastern Europe", IMF Working Paper WP/07/248 (Washington: International Monetary Fund).

Moussa, B., 2010, "On the Development of Western African Accounting System", Economics and Management School, Wuhan University.

Mueller, J., Yackovlev, I., and H, Weisfeld, 2009, “The Global Financial Crisis: Impact on WAEMU Member Countries and Policy Options", IMF Staff Position Note SPN/09/16 (Washington: International Monetary Fund).

Sacerdoti, E., 2005, “Access to Bank Credit in Sub-Saharan Africa", IMF Working Paper WP/05/166 (Washington: International Monetary Fund). 
Table 1. Descriptive Statistics, 1997-2009

\begin{tabular}{|c|c|c|c|c|c|}
\hline Variable & Observations & Mean & Std. Dev. & Min & $\operatorname{Max}$ \\
\hline Credit to private/GDP & 168 & 0.16 & 0.15 & 0.01 & 0.85 \\
\hline WAEMU_dummy & 208 & 0.50 & 0.50 & 0.00 & 1.00 \\
\hline Inflation & 206 & 0.05 & 0.04 & -0.09 & 0.16 \\
\hline GDP per capita & 208 & 6.28 & 1.03 & 4.73 & 8.94 \\
\hline Rule of law & 160 & -0.44 & 0.66 & -1.90 & 1.05 \\
\hline Political Stability & 160 & -0.26 & 0.88 & -2.28 & 1.13 \\
\hline Internet per hundred & 207 & 2.55 & 4.36 & 0.00 & 25.00 \\
\hline Credit coverage & 67 & 2.76 & 4.84 & 0.00 & 21.80 \\
\hline Property & 160 & 38.41 & 16.51 & 10.00 & 75.00 \\
\hline
\end{tabular}

Table 2. Correlation Matrix

\begin{tabular}{lllllllll}
1 & 2 & 3 & 4 & 5 & 6 & 7 & 8 & 9 \\
\hline
\end{tabular}

Credit to private/GDP $\quad 1 \quad 1.00$

Waemu_dummy $\quad 2 \quad-0.26 \quad 1.00$

Inflation $\quad 3 \quad 0.08 \quad-0.47 \quad 1.00$

$\begin{array}{llllll}\text { GDP per capita } & 4 & 0.76 & -0.26 & 0.12 & 1.00\end{array}$

$\begin{array}{lllllll}\text { Rule of law } & 5 & 0.72 & -0.45 & 0.09 & 0.74 & 1.00\end{array}$

$\begin{array}{llllllll}\text { Political Stability } & 6 & 0.52 & -0.10 & -0.05 & 0.58 & 0.76 & 1.00\end{array}$

$\begin{array}{lllllllll}\text { Internet per hundred } & 7 & 0.86 & -0.26 & 0.11 & 0.64 & 0.56 & 0.39 & 1.00\end{array}$

$\begin{array}{llllllllll}\text { Credit coverage } & 8 & 0.61 & 0.03 & -0.34 & 0.44 & 0.33 & 0.37 & 0.65 & 1.00\end{array}$

$\begin{array}{lllllllllll}\text { Property } & 9 & 0.65 & -0.38 & 0.03 & 0.77 & 0.86 & 0.58 & 0.53 & 0.38 & 1.00\end{array}$ 
Table 3. Variables definitions

\begin{tabular}{|c|c|c|}
\hline Variable & Definition & Source \\
\hline Credit to private/GDP & Credit to the private sector as percentage of GDP & IFS \\
\hline Waemu_dummy & Take value 1 if the country belongs to the WAEMU & \\
\hline Inflation & Inflation rate & IFS \\
\hline GDP per capita & Gross Domestic Product per capita & IFS \\
\hline \multirow[t]{2}{*}{ Rule of law } & $\begin{array}{l}\text { Rule of Law captures perceptions of the extent to which } \\
\text { agents have confidence in and abide by the rules of } \\
\text { society, and in particular the quality of contract } \\
\text { enforcement, property rights, the police, and the courts, } \\
\text { as well as the likelihood of crime and violence. Estimate } \\
\text { gives the country's score on the aggregate indicator, in } \\
\text { units of a standard normal distribution, i.e. ranging from }\end{array}$ & \\
\hline & approximately -2.5 to 2.5 & Worldwide Governance Indicators (World Bank) \\
\hline \multirow[t]{2}{*}{ Political Stability } & $\begin{array}{l}\text { Political Stability and Absence of Violence/Terrorism } \\
\text { captures perceptions of the likelihood that the } \\
\text { government will be destabilized or overthrown by } \\
\text { unconstitutional or violent means, including politically- } \\
\text { motivated violence and terrorism. Estimate gives the } \\
\text { country's score on the aggregate indicator, in units of a } \\
\text { standard normal distribution, i.e. ranging from }\end{array}$ & \\
\hline & approximately -2.5 to 2.5 & Worldwide Governance Indicators (World Bank) \\
\hline Internet per hundred & $\begin{array}{l}\text { Internet users are people with access to the worldwide } \\
\text { network (number per hundred people) }\end{array}$ & World Development Indicators (World Bank) \\
\hline \multirow[t]{2}{*}{ Credit coverage } & $\begin{array}{l}\text { Public credit registry coverage reports the number of } \\
\text { individuals and firms listed in a public credit registry with } \\
\text { current information on repayment history, unpaid debts, } \\
\text { or credit outstanding. The number is expressed as a }\end{array}$ & \\
\hline & percentage of the adult population & World Development Indicators (World Bank) \\
\hline \multirow[t]{2}{*}{ Property } & $\begin{array}{l}\text { An index measuring the ability of individuals to } \\
\text { accumulate private property, secured by clear laws that }\end{array}$ & \\
\hline & are fully enforced by the state & Heritage Foundation Database \\
\hline
\end{tabular}




\begin{tabular}{|c|c|c|c|c|c|c|c|}
\hline \multicolumn{8}{|c|}{ Table 4. Financial Development in WAEMU and HGNOE in SSA, 1997-2009 } \\
\hline VARIABLES & (1) & $(2)$ & (3) & (4) & (5) & (6) & (7) \\
\hline \multirow[t]{2}{*}{ Waemu_dummy } & -0.028 & -0.003 & -0.029 & -0.010 & 0.013 & -0.023 & 0.012 \\
\hline & $0.005 * * *$ & 0.007 & $0.007 * * *$ & 0.006 & 0.014 & $0.006 * * *$ & 0.012 \\
\hline \multirow[t]{2}{*}{ Inflation } & -0.171 & -0.180 & -0.273 & -0.126 & -0.063 & -0.164 & -0.156 \\
\hline & $0.067 * * *$ & $0.075^{* * *}$ & $0.076 * * *$ & $0.072 *$ & 0.132 & $0.068 * * *$ & 0.097 \\
\hline \multirow[t]{2}{*}{ GDP per capita } & 0.114 & 0.083 & 0.089 & 0.056 & 0.074 & 0.099 & 0.044 \\
\hline & $0.003 * * *$ & $0.003 * * *$ & $0.004 * * *$ & $0.006 * * *$ & $0.011 * * *$ & $0.004^{* * *}$ & $0.008 * * *$ \\
\hline \multirow[t]{2}{*}{ Rule of law } & & 0.078 & & & & & 0.045 \\
\hline & & $0.006 * * *$ & & & & & $0.020 * * *$ \\
\hline \multirow[t]{2}{*}{ Political Stability } & & & 0.033 & & & & 0.009 \\
\hline & & & $0.003 * * *$ & & & & 0.009 \\
\hline \multirow[t]{2}{*}{ Internet per hundred } & & & & 0.020 & & & 0.018 \\
\hline & & & & $0.002 * * *$ & & & $0.002 * * *$ \\
\hline \multirow[t]{2}{*}{ Credit coverage } & & & & & 0.010 & & \\
\hline & & & & & $0.004 * * *$ & & \\
\hline \multirow[t]{2}{*}{ Property } & & & & & & 0.001 & 0.001 \\
\hline & & & & & & $0.000 * * *$ & 0.001 \\
\hline \multirow[t]{2}{*}{ Constant } & -0.519 & -0.300 & -0.349 & -0.217 & -0.337 & -0.479 & -0.151 \\
\hline & $0.021 * * *$ & $0.024 * * *$ & $0.027^{* * *}$ & $0.030 * * *$ & $0.067 * * *$ & 0.023 & $0.054 * * *$ \\
\hline Observations & 167 & 132 & 132 & 167 & 52 & 138 & 122 \\
\hline Number of countries & 17 & 17 & 17 & 17 & 15 & 17 & 17 \\
\hline Chi square (Wald Test) & 1231.91 & 1638.05 & 727.28 & 489.96 & 116.77 & 1267.99 & 588.84 \\
\hline
\end{tabular}

\begin{tabular}{|lcc|}
\hline \multicolumn{3}{|c|}{ Table 5. Structural variables in 2010 } \\
(in percent) \\
\hline Variables & Côte d'Ivoire & Mozambique \\
\hline GDP (constant 2000 US\$) & 11,603 & 8,972 \\
GDP per capita (constant 2000 US\$) & 588 & 384 \\
Population (millions) & 22.0 & 21.6 \\
Population density & 62.1 & 29.7 \\
Urban population (in percent of total population) & 50.1 & 38.4 \\
Rural population (in percent of total population) & 49.9 & 61.6 \\
Dependency ratios & 80.1 & 89.5 \\
\hline Sources: WDI, IFS & & \\
\hline
\end{tabular}


Table 6. Main Financial Reforms in 2003-10

\begin{tabular}{|c|c|c|}
\hline Reforms & Mozambique & Côte d'Ivoire \\
\hline Banking supervision & Risk-based supervision introduced. & $\begin{array}{l}\text { No reform. Overall-compliance } \\
\text { supervisory }\end{array}$ \\
\hline Accounting standards & Implementation of IFRS (IAS) & $\begin{array}{l}\text { Uniform accounting standards for } \\
\text { WAEMU members (SYSCO) }\end{array}$ \\
\hline Payment systems & Payment and settlements strengthened & $\begin{array}{l}\text { Payment and settlements systems } \\
\text { strengthened }\end{array}$ \\
\hline Credit information & $\begin{array}{l}\text { Expansion of the coverage and range of information collected } \\
\text { by the credit registry. Legal framework to allow credit } \\
\text { registries enacted. }\end{array}$ & No reforms. \\
\hline $\begin{array}{l}\text { Legal and judicial } \\
\text { framework }\end{array}$ & $\begin{array}{l}\text { Commercial code has been reviewed; specialized commercial } \\
\text { court and special division of Maputo city court to execute } \\
\text { judgments have been established; the code of civil procedure } \\
\text { and the Notary Office modernized; the legal framework for } \\
\text { secured transactions updated. }\end{array}$ & No reforms \\
\hline $\begin{array}{l}\text { Microfinance } \\
\text { institutions }\end{array}$ & Legislation on microfinance enacted. & $\begin{array}{l}\text { Legislation on microfinance enacted, } \\
\text { but the staffing and supervision need } \\
\text { to be strengthened. The financial } \\
\text { position of much of the sector is } \\
\text { critical. }\end{array}$ \\
\hline
\end{tabular}




\section{ANNEX 1. FINANCIAL POSSIBILITY FRONTIER: BENCHMARKING WAEMU AGAINST HGNOES}

The results presented in this section are based on the concept of financial benchmarking methodology presented in Beck et al. 2009. The benchmarks were estimated using the FinStats, a tool developed by the World Bank that implements the methodology in Beck 2009 and estimates the financial benchmarks for the quasi-totality of countries in the world. The concept of financial benchmarking is predicated on the idea that there are structural factor that determine the level of financial development a country can attain. Some factors are conducive to financial sector development (e.g., income levels) and others inhibit it (e.g., low density of population, which makes infrastructure deployment costly relative to the population served and minimizes the benefit of economies of scale in banking). The benchmarking allows for cross-country comparisons to see how a specific country is doing relative to other countries with similar structural characteristics and at similar stage of development. The benchmarking approach in Beck, assumes that once appropriate controls are introduced, the process of financial development is broadly comparable across countries and stages of development. Financial sector development is affected three types of factors: economic development, other structural characteristics and the policy environment.

$$
X_{t}=\alpha Y_{t}+\beta P_{t}+\gamma Z_{t}+\varepsilon_{t}
$$

Where $\mathrm{X}$ is an indicator of financial sector development, $\mathrm{Y}$ is an indicator of economic development; $\mathrm{P}$ represents the policy environment, $\mathrm{Z}$ is a vector of structural characteristics, and is a residual.

Economic development is captured by income per capita. Demand for financial services increases as income grows. On the supply side, richer countries have better infrastructure and higher competition, which lower the price of financial services. Income per capita is endogenous, but financial sector development affects income per capita with a delay. The reason for this is that changes in the policy environment affect the financial sector first, and the financial sector in turn then affects economic growth. Therefore, we can write:

$$
Y_{t}=\alpha^{\prime} P_{t}+\beta^{\prime} P_{t-1}+\gamma^{\prime} Z_{t}+\varepsilon_{t}^{\prime}
$$

The policy environment does not change radically overnight. Good policies today are generally linked to the good policies of yesterday but also to today's innovations.

$$
P_{t}=\alpha " P_{t-1}+v_{t}
$$

The structural variables included in the benchmarking analysis are a set of factors that are considered as external to policy, at least in the short run. These factors include: population, 
age dependency, a time factor, and special circumstances. Countries with larger population and higher population density can have deeper and low cost of providing financial services thanks to economies of scale. The share of non-working young and old populations (age dependency) affects saving and lending patterns. Over time, all financial systems tend to improve, albeit at different speed, because of global factors that "lift all boats". To account for this, a time trend is included in the regression. Many special factors affect financial sector development: in oil exporting countries, income per capita can be out of proportion with the financial and overall economic development of the country. In contrast, offshore financial centers have a financial sector that is disproportionately larger than the overall economy.

When one runs a regression of financial development on economic development and structural factors only, policy innovations are captured by the residual. To see this, one can substitute equations (2) and (3) into (1), and get the following reduced form expression:

$$
X_{t}=\left(\alpha+\frac{\beta \alpha^{\prime \prime}}{\alpha^{\prime} \alpha^{\prime \prime}+\beta^{\prime}}\right) Y_{t}+\left(\gamma-\frac{\beta \alpha^{\prime \prime} \gamma^{\prime}}{\alpha^{\prime} \alpha^{\prime \prime}+\beta^{\prime}}\right) Z_{t}+\left(\varepsilon_{t}-\frac{\alpha^{\prime \prime}}{\alpha^{\prime} \alpha^{\prime \prime}+\beta^{\prime}} \varepsilon_{t}^{\prime}+\frac{\beta \beta^{\prime}}{\alpha^{\prime} \alpha^{\prime \prime}+\beta^{\prime}} v_{t}\right)
$$

The policy innovation factor is now in the residual. When the benchmark is constructed using the economic and structural variables ( $\mathrm{Y}$ and $\mathrm{Z}$ ), the distance between the benchmark and the actual level of financial development is assumed to reflect the country's policy environment. Countries with better policies (higher $v$ ) would tend to have more developed financial sectors compared to countries with worse policies.

FinStats estimates equation (4) via quantile regressions, ${ }^{1}$ using data from 177 countries. It then compares a given country to its own potential (benchmark) or to its comparator countries. In the first approach, the country's benchmark is calculated using its economic and structural variables in equation (4). In the second approach, comparator countries are chosen based on their similarity with the reference country on two dimensions: GDP per capita and populations. The comparator countries are those with the smallest distance to the reference country, where distance is calculated as follows:

$$
\Delta_{i j}=w_{g d p p c}\left|\operatorname{PR}\left(g d p_{i}\right)-P R\left(g d p p c_{j}\right)\right|+\left(1-w_{g d p p c}\right)\left|\operatorname{PR}\left(P O P_{i}\right)-P R\left(P O P_{j}\right)\right|
$$

Where, PR is the percentile rank of the country. FinStats uses the expected $25^{\text {th }}$ and $75^{\text {th }}$ percentiles.

\footnotetext{
${ }^{1}$ The quantile regressions are used to reduce the impact of outliers and produce different expected values to gauge the range of financial sector performance.
} 
ANNEX 2. BenChMARKIng WAEMU Countries Against Their Potential
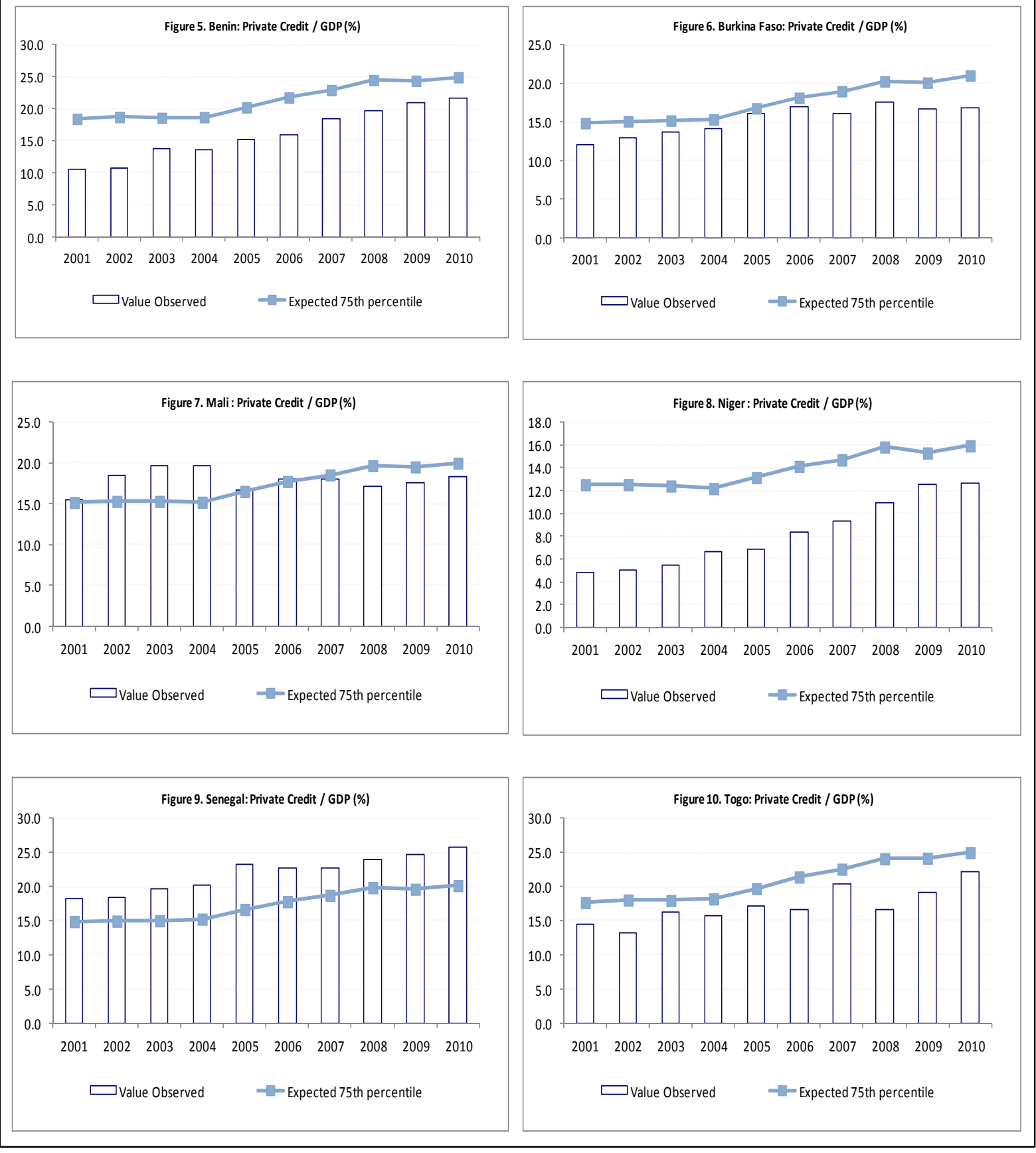

CInternational Monetary Fund. Not for Redistribution 